\title{
Longispora albida gen. nov., sp. nov., a novel genus of the family Micromonosporaceae
}

\author{
Correspondence \\ Yōko Takahashi \\ ytakaha@lisci.kitasato-u.ac.jp
}

\author{
Atsuko Matsumoto, ${ }^{1}$ Yōko Takahashi, ${ }^{1}$ Mayumi Shinose, ${ }^{1}$ Akio Seino, ${ }^{1}$ \\ Yuzuru Iwai ${ }^{2}$ and Satoshi Ōmura ${ }^{1,2}$ \\ ${ }^{1}$ Kitasato Institute for Life Sciences, Kitasato University, 5-9-1 Shirokane, Minato-ku, Tokyo \\ 108-8641, Japan \\ ${ }^{2}$ The Kitasato Institute, 5-9-1 Shirokane, Minato-ku, Tokyo 108-8641, Japan
}

\begin{abstract}
A novel actinomycete strain was isolated from a soil sample collected in Japan by using gellan gum as a solidifying agent. Spore-chains from the short sporophores were straight and each had more than 20 spores per chain. Spores possessed no motility. Cell-wall peptidoglycan contained meso-diaminopimelic acid, glycine, alanine and glutamic acid; whole-cell hydrolysates contained arabinose, galactose and xylose. The acyl type of the peptidoglycan was glycolyl. The predominant menaquinones were $\mathrm{MK}-10\left(\mathrm{H}_{4}\right)$ and $\mathrm{MK}-10\left(\mathrm{H}_{6}\right)$; MK-10 $\left(\mathrm{H}_{8}\right)$ was a minor component. Mycolic acids were not detected. The diagostic phospholipid was phosphatidylethanolamine. Cellular fatty acids included heptadecenoic $\left(C_{17: 1}\right), 14$-methylpentadecanoic ( $\left.\mathrm{i}-\mathrm{C}_{16: 0}\right)$ and octadecenoic $\left(\mathrm{C}_{18: 1}\right)$ acids. The $\mathrm{G}+\mathrm{C}$ content of the DNA was $70 \mathrm{~mol} \%$. On the basis of morphogical and chemotaxonomic properties and phylogenetic analysis based on $16 \mathrm{~S}$ rDNA sequence data, it is proposed that this strain should be classified in a novel genus and species, Longispora albida gen. nov., sp. nov., in the family Micromonosporaceae. The type strain is K97-0003 ${ }^{\top}\left(=\right.$ NRRL B-24201 ${ }^{\top}=$ JCM $\left.11711^{\top}\right)$.
\end{abstract}

\section{INTRODUCTION}

Members of the order Actinomycetales offer possibilities for the discovery of new bioactive compounds. Many new bioactive metabolites have been found from Streptomyces strains that were isolated from soil, in which strains of this genus are distributed at a high frequency. An efficient way to find new bioactive metabolites is by the discovery of new micro-organisms and many approaches have been used for this purpose, e.g. isolation from plants or soil in particular environments, pre-treatments of soil samples and changing the formulation of isolation media. As one of these various approaches, we tried to isolate actinomycete strains by using gellan gum, which was used for selective isolation of the genus Actinobispora Jiang et al. 1991 by Suzuki et al. (1998) as a solidifying agent, instead of agar. As a result, we isolated strain $\mathrm{K} 97-0003^{\mathrm{T}}$, which produces actinohivin, a novel anti-HIV (human immunodeficiency virus) protein found in the culture broth of the strain by a syncytium formation assay system (Chiba et al., 2001).

Strain $\mathrm{K} 97-0003^{\mathrm{T}}$ grew better on gellan gum media than on agar media. Morphological and chemotaxonomic

Published online ahead of print on 11 April 2003 as DOI 10.1099/ ijs.0.02595-0.

Abbreviation: DAP, diaminopimelic acid.

The GenBank/EMBL/DDBJ accession number for the $16 \mathrm{~S}$ rDNA sequence of strain $\mathrm{K}^{\mathrm{N}} \mathrm{7}-0003^{\mathrm{T}}$ is $\mathrm{AB} 089241$. properties of the strain indicated that it belonged to the family Micromonosporaceae (Krasil'nikov 1938, emend. Koch et al. 1996). Phylogenetic analysis based on 16S rDNA sequence data showed that the strain formed a lineage within the family Micromonosporaceae, but not within any existing genus. Therefore, we propose that the strain should be classified as a novel genus and species, Longispora albida gen. nov., sp. nov.

\section{METHODS}

Micro-organisms. Strain $\mathrm{K} 97-0003^{\mathrm{T}}$ was isolated from a soil sample collected at Suginami, Tokyo, Japan, by culture on water/ proline/gellan gum medium [tap water, $1 \%$ proline, $1 \%$ gellan gum (Kanto Chemical); unadjusted $\mathrm{pH}]$ at $27^{\circ} \mathrm{C}$.

Morphology. Morphological characteristics of the strain were observed by scanning electron microscopy (model JSM-5600; JEOL) following incubation on $1 / 10 \mathrm{~V} 8$ juice/gellan gum medium [2\% V8 juice (Campbell's soup), $0.03 \% \mathrm{CaCO}_{3}, 1 \%$ gellan gum, tap water, $\mathrm{pH} 7 \cdot 2$ ] that contained $0.06 \% \mathrm{CaCl}_{2} \cdot 2 \mathrm{H}_{2} \mathrm{O}$ for 20 days at $27^{\circ} \mathrm{C}$ and fixation by $4 \%$ osmium tetroxide vapour.

Cultural and physiological characteristics. Cultural and physiological characteristics of the strain were determined following incubation for 2 weeks at $27^{\circ} \mathrm{C}$ on media recommended by Waksman (1961) and the International Streptomyces Project (Shirling \& Gottlieb, 1966). Colour names and hue numbers were determined according to the Color Harmony Manual (Taylor et al., 1958). The ability of the strain to grow on a range of sole carbon sources at $1 \%(\mathrm{w} / \mathrm{v})$ was determined in carbon utilization media (Pridham \& 
Gottlieb, 1948) with agar or gellan gum and agar medium of yeast nitrogen base without amino acids (Difco), as described by Asano \& Kawamoto (1986). $\mathrm{NaCl}$ tolerance and $\mathrm{pH}$ and temperature ranges for growth were determined on yeast extract/malt extract agar (ISP medium 2). Media for spore formation were as follows: ISP media (2, 3 and 7$)$, glucose/peptone, nutrient, water/proline ( $1 \%$ proline, tap water), $1 / 10 \mathrm{~V} 8$ and $1 / 10 \mathrm{~V} 8$ that contained $0.06 \% \mathrm{CaCl}_{2} \cdot 2 \mathrm{H}_{2} \mathrm{O}$; $1 \cdot 5 \%$ agar or $1 \%$ gellan gum was used as the solidifying agent.

Chemotaxonomic characterization. Isomers of diaminopimelic acid (DAP) in whole-cell hydrolysates were determined by TLC following standard methods (Becker et al., 1965; Hasegawa et al., 1983 ) and the $\mathrm{N}$-acyl types of muramic acid were determined by the method of Uchida \& Aida (1977). Purified cell wall was obtained by the method of Kawamoto et al. (1981) and the amino acid composition of hydrolysed cell walls was determined by TLC. Whole-cell sugars were analysed after Becker et al. (1965), presence of mycolic acids was examined by TLC following Tomiyasu (1982) and phospholipids were extracted and identified following the method of Minnikin et al. (1977). Menaquinones were extracted and purified by the method of Collins et al. (1977), then analysed by HPLC (model 802-SC; Jasco) on a chromatograph equipped with a CAPCELL PAK C18 column (Shiseido) (Tamaoka et al., 1983). Methyl esters of cellular fatty acids were prepared by direct transmethylation with methanolic hydrochloride and analysed by using GLC (model GC-17A; Shimadzu) with a DB-23 capillary column $(0.25 \mathrm{~mm} \times 30 \mathrm{~m}$; J\&W Scientific) (Suzuki \& Komagata, 1983).

DNA base composition. Chromosomal DNA was prepared by using the procedure of Marmur (1961) and the G+C content of the DNA preparations was determined by the HPLC method of Tamaoka \& Komagata (1984).

Analysis of 16S rDNA sequence. Chromosomal DNA was prepared by using the same method as above. 16S rDNA was PCRamplified by using previously described methods (Takahashi et al., 2002) and was sequenced directly on an ABI model 377A automatic DNA sequencer by using a PRISM Ready Reaction Dye Primer Cycle Sequencing kit (Applied Biosystems). CLUSTAL W software (Thompson et al., 1994) was used for multiple alignment of selected sequences, for calculating evolutionary distances (Kimura, 1980) and similarity values and for constructing a phylogenetic tree based on the neighbour-joining method (Saitou \& Nei, 1987). Data were resampled with 1000 bootstrap replications (Felsenstein, 1985). For the phylogenetic tree by the maximum-likelihood method, PAUP version 4.0 beta 8 (Swofford, 2001) was used.

\section{RESULTS AND DISCUSSION}

\section{Cultural and morphological characteristics}

After incubation for 2 weeks at $27^{\circ} \mathrm{C}$, strain $\mathrm{K} 97-0003^{\mathrm{T}}$ grew well on yeast extract/malt extract agar, oatmeal agar, peptone/yeast extract/iron agar and nutrient agar, but aerial mycelia did not grow (Table 1). After substitution of agar by gellan gum, aerial mycelia grew slightly on a few media and spores were produced well on 1/10 V8 gellan gum medium that contained $\mathrm{CaCl}_{2}$ (Table 2).

Short sporophores branched from the vegetative mycelia; spore-chains from the sporophores were straight and each had more than 20 spores per chain. Spores were cylindrical, $0 \cdot 4-0 \cdot 5 \times 1 \cdot 0-1 \cdot 4 \mu \mathrm{m}$ and had a smooth surface (Fig. 1). Whirls, sclerotic granules, sporangia and flagellated spores were not observed.

\section{Physiological characteristics}

Strain $\mathrm{K} 97-0003^{\mathrm{T}}$ grew at $12-37^{\circ} \mathrm{C}$ and the optimum range was $21-33^{\circ} \mathrm{C}$. No melanoid pigment was produced; tests for reduction of nitrate, liquefaction of gelatin and coagulation and peptonization of milk were positive. Hydrolysis of starch was negative on gellan gum medium and the strain did not grow on agar medium. The strain utilized D-glucose, but not L-arabinose, D-fructose, myo-inositol, D-mannitol, melibiose, raffinose, L-rhamnose, sucrose or D-xylose, on agar and gellan gum media. Cellulose was not decomposed. The $\mathrm{pH}$ range for growth was $6-9$. The strain did not grow in the presence of $2 \% \mathrm{NaCl}$.

\section{Chemotaxonomic characteristics}

Strain $\mathrm{K} 97-0003^{\mathrm{T}}$ contained arabinose, galactose and xylose in whole-cell hydrolysates. Cell-wall peptidoglycan contained meso-DAP, glycine, alanine and glutamic acid. The acyl type of the peptidoglycan was glycolyl. Predominant menaquinones were MK-10 $\left(\mathrm{H}_{4}\right)$ and $\mathrm{MK}-10\left(\mathrm{H}_{6}\right)$ and a minor menaquinone component was MK-10 $\left(\mathrm{H}_{8}\right)$. Mycolic acids were not detected. The only phospholipid detected

Table 1. Growth and cultural characteristics of strain $\mathrm{K} 97-0003^{\top}$

Strain $\mathrm{K} 97-0003^{\mathrm{T}}$ did not grow on inorganic salts/starch agar (ISP medium 4), sucrose/nitrate agar, glucose/nitrate agar or glycerol/calcium malate agar. No aerial mycelia were produced on any medium.

\begin{tabular}{|c|c|c|}
\hline Medium & Growth & Reverse colour \\
\hline Yeast extract/malt extract agar (ISP 2) & Moderate; light ivory (2ca) & Cream $\left(1 \frac{1}{2} \mathrm{ca}\right)$ \\
\hline Oatmeal agar (ISP 3) & Moderate; alabaster tint (13ba) & Blue tint (15ba) \\
\hline Glycerol/asparagine agar (ISP 5) & 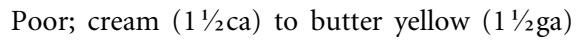 & Cream $\left(1 \frac{1}{2} \mathrm{ca}\right)$ to light yellow $\left(1 \frac{1}{2} \mathrm{ea}\right)$ \\
\hline Glucose/asparagine agar & Poor; pearl (2ba) & Yellow tint (1ba) \\
\hline Peptone/yeast extract/iron agar (ISP 6) & Moderate; pearl pink (3ca) & Colonial yellow (1ga) \\
\hline Tyrosine agar (ISP 7) & Poor; light ivory (2ca) & Cream $\left(1 \frac{1}{2} \mathrm{ca}\right)$ \\
\hline Glucose/peptone agar & Poor; cream $\left(1 \frac{1}{2} \mathrm{ca}\right)$ & Cream $\left(1 \frac{1}{2} \mathrm{ca}\right)$ \\
\hline Nutrient agar & Moderate; light wheat (2ea) & Butter yellow (1 1/2ga) \\
\hline
\end{tabular}


Table 2. Aerial mycelium formation of strain $\mathrm{K} 97-0003^{\top}$ on various media

- , Negative; $+{ }^{\mathrm{t}}$, trace aerial mycelium observed with a light microscope; + , poor aerial mycelium; ++ , aerial mycelium produced (better than + ).

\begin{tabular}{|c|c|c|c|c|}
\hline \multirow[t]{2}{*}{ Medium } & \multicolumn{2}{|r|}{ Agar } & \multicolumn{2}{|c|}{ Gellan gum } \\
\hline & Growth & Aerial mycelium & Growth & Aerial mycelium \\
\hline Yeast extract/malt extract (ISP 2) & + & $+{ }^{\mathrm{t}}$ & ++ & $+{ }^{\mathrm{t}}$ \\
\hline Oatmeal (ISP 3) & + & - & + & - \\
\hline Tyrosine (ISP 7) & + & - & + & + \\
\hline Glucose/peptone & + & - & ++ & - \\
\hline Nutrient & + & - & + & - \\
\hline Water/proline & + & - & ++ & - \\
\hline $1 / 10 \mathrm{~V} 8$ & + & - & + & + \\
\hline $1 / 10 \mathrm{~V} 8+\mathrm{CaCl}_{2}$ & + & $+{ }^{\mathrm{t}}$ & + & ++ \\
\hline
\end{tabular}

was phosphatidylethanolamine; phosphatidylcholine, phosphatidylglycerol and an unidentified phospholipid that contains glucosamine were absent. This corresponds to phospholipid pattern II sensu of Lechevalier et al. (1977). Predominant cellular fatty acid components were heptadecenoic $\left(\mathrm{C}_{17: 1}, 24 \%\right)$, 14-methylpentadecanoic (i- $\mathrm{C}_{16: 0}$, $20 \%)$ and octadecenoic $\left(\mathrm{C}_{18: 1}, 16 \%\right)$ acids (Table 3$)$. The $\mathrm{G}+\mathrm{C}$ content of the DNA was $70 \mathrm{~mol} \%$.

The acyl type of strain K97-0003 ${ }^{\mathrm{T}}$ was glycolyl; mycolic acids were absent. These two characteristics show that this strain is a member of the family Micromonosporaceae, the family Glycomycetaceae or the genus Microbacterium (OrlaJensen, 1919) in the family Microbacteriaceae (Table 4). However, its morphology and chemotaxonomic characters differed from those of members of the genus Microbacterium and of the only genus, Glycomyces (Labeda et al., 1985), of the family Glycomycetaceae. As a result, this strain was placed in the family Micromonosporaceae.

At present, the family Micromonosporaceae consists of

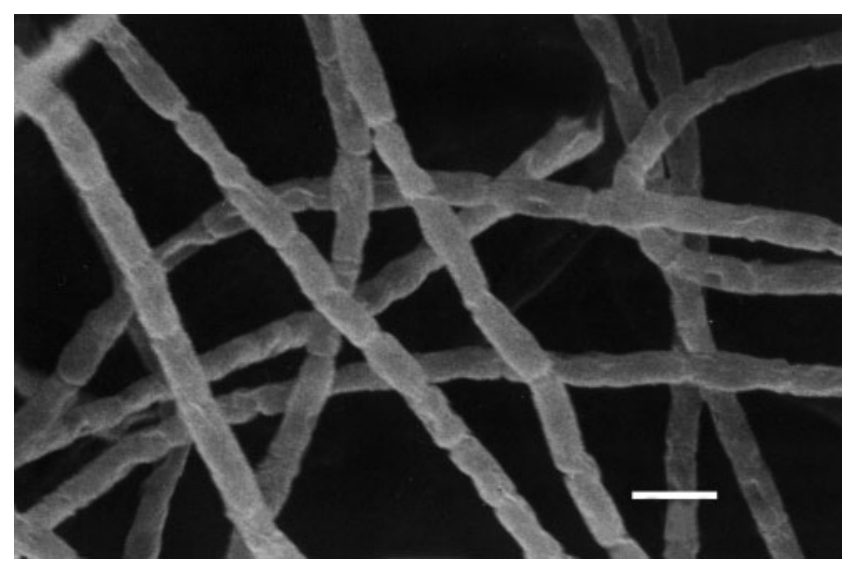

Fig. 1. Scanning electron micrograph of spore-chains of strain $\mathrm{K} 97-0003^{\top}$, grown on $1 / 10 \mathrm{~V} 8+\mathrm{CaCl}_{2}$ gellan gum medium for 20 days at $27^{\circ} \mathrm{C}$. Bar, $1 \mu \mathrm{m}$. eleven genera: Actinoplanes (Couch, 1950), Asanoa (Lee \& Hah, 2002), Catellatospora (Asano \& Kawamoto, 1986), Catenuloplanes (Yokota et al., 1993), Couchioplanes (Tamura et al., 1994), Dactylosporangium (Thiemann et al., 1967), Micromonospora (Ørskov, 1923), Pilimelia (Kane, 1966), Spirilliplanes (Tamura et al., 1997), Verrucosispora (Rheims

Table 3. Fatty acid composition of strain $\mathrm{K} 97-0003^{\top}$

\begin{tabular}{|c|c|}
\hline Fatty acid & Composition (\%) \\
\hline \multicolumn{2}{|l|}{ Saturated: } \\
\hline $\mathrm{C}_{14: 0}$ & $0 \cdot 1$ \\
\hline $\mathrm{C}_{15: 0}$ & $1 \cdot 2$ \\
\hline $\mathrm{C}_{16: 0}$ & $1 \cdot 1$ \\
\hline $\mathrm{C}_{17: 0}$ & $4 \cdot 6$ \\
\hline $\mathrm{C}_{18: 0}$ & $0 \cdot 5$ \\
\hline $\mathrm{C}_{19: 0}$ & $2 \cdot 1$ \\
\hline \multicolumn{2}{|l|}{ Unsaturated: } \\
\hline $\mathrm{C}_{16: 1} \omega 9$ & $0 \cdot 1$ \\
\hline $\mathrm{C}_{16: 1} \omega \mathrm{A}^{*}$ & $0 \cdot 5$ \\
\hline $\mathrm{C}_{17: 1} \omega \mathrm{B}^{\star}$ & $8 \cdot 5$ \\
\hline $\mathrm{C}_{17: 1} \omega \mathrm{C}^{\star}$ & $1 \cdot 2$ \\
\hline $\mathrm{C}_{17: 1} \omega \mathrm{D}^{*}$ & $14 \cdot 3$ \\
\hline $\mathrm{C}_{18: 1} \omega 9$ & $2 \cdot 3$ \\
\hline $\mathrm{C}_{18: 1} \omega 11$ & $0 \cdot 3$ \\
\hline $\mathrm{C}_{18: 1} \omega \mathrm{E}^{\star}$ & $13 \cdot 1$ \\
\hline $\mathrm{C}_{19: 1} \omega \mathrm{F}^{*}$ & $6 \cdot 5$ \\
\hline $\mathrm{C}_{19: 1} \omega \mathrm{G}^{\star}$ & $2 \cdot 2$ \\
\hline \multicolumn{2}{|l|}{ Branched: } \\
\hline iso- $\mathrm{C}_{14: 0}$ & $0 \cdot 5$ \\
\hline iso- $\mathrm{C}_{15: 0}$ & $3 \cdot 1$ \\
\hline anteiso- $\mathrm{C}_{15: 0}$ & $0 \cdot 7$ \\
\hline iso- $\mathrm{C}_{16: 0}$ & $20 \cdot 1$ \\
\hline iso- $\mathrm{C}_{17: 0}$ & $7 \cdot 0$ \\
\hline anteiso- $\mathrm{C}_{17: 0}$ & $7 \cdot 5$ \\
\hline $\mathrm{C}_{18: 0} \dagger^{\dagger}$ & $2 \cdot 5$ \\
\hline
\end{tabular}

${ }^{\star} \mathrm{A}-\mathrm{G}$ : Double-bond positions of these fatty acids are not known. $\dagger$ This fatty acid is either iso- or anteiso-branched. 
Table 4. Comparison of morphological and chemotaxonomic characteristics of strain $\mathrm{K} 97-0003^{\top}$ and genera that contain $\mathrm{N}$-glycolyl muramic acid in the peptidoglycan and no mycolic acids

Taxa: 1, K97-0003 ${ }^{\mathrm{T}}$; 2, Micromonospora; 3, Actinoplanes; 4, Asanoa; 5, Catellatospora; 6, Catenuloplanes; 7, Couchioplanes; 8, Dactylosporangium; 9, Pilimelia; 10, Spirilliplanes; 11, Verrucosispora; 12, Virgisporangium; 13, Glycomyces; 14, Microbacterium. Data were taken from Labeda et al. (1985), Stackebrandt \& Kroppenstedt (1987), Vobis (1989), Goodfellow et al. (1990), Evtushenko et al. (1991), Tamura et al. (1994, 1997, 2001), Rheims et al. (1998), Takeuchi \& Hatano (1998), Kudo et al. (1999), Lee et al. (2000), Lee \& Hah (2002) and Zlamala et al. (2002). ND, Not determined; D, a substantial proportion of species differ.

\begin{tabular}{|c|c|c|c|c|c|c|c|c|c|c|c|c|c|c|}
\hline Characteristic & 1 & 2 & 3 & 4 & 5 & 6 & 7 & 8 & 9 & 10 & 11 & 12 & 13 & 14 \\
\hline Spore-chains & + & - & - & + & + & + & + & - & - & + & - & - & + & - \\
\hline Spore motility & - & - & + & - & - & + & + & + & + & + & - & + & - & $\mathrm{D}$ \\
\hline Diamino acid & $\begin{array}{l}\text { meso- } \\
\text { DAP }\end{array}$ & $\begin{array}{l}\text { meso- } \\
\text { DAP }\end{array}$ & $\begin{array}{l}\text { meso- } \\
\text { DAP }\end{array}$ & $\begin{array}{l}\text { meso- } \\
\text { DAP }\end{array}$ & $\begin{array}{l}\text { meso- } \\
\text { DAP }\end{array}$ & L-Lys & L-Lys & $\begin{array}{l}\text { meso- } \\
\text { DAP }\end{array}$ & $\begin{array}{l}\text { meso- } \\
\text { DAP }\end{array}$ & $\begin{array}{l}\text { meso- } \\
\text { DAP }\end{array}$ & $\begin{array}{l}\text { meso- } \\
\text { DAP }\end{array}$ & $\begin{array}{l}\text { meso- } \\
\text { DAP }\end{array}$ & $\begin{array}{l}\text { meso- } \\
\text { DAP }\end{array}$ & L-Lys/D-Orn \\
\hline $\begin{array}{l}\text { Major menaquinones } \\
\text { (MK-) }\end{array}$ & $10\left(\mathrm{H}_{4,6}\right)$ & $10\left(\mathrm{H}_{4,6}\right), 9\left(\mathrm{H}_{4,6}\right)$ & $9\left(\mathrm{H}_{4}\right)$ & $10\left(\mathrm{H}_{6,8}\right)$ & $\begin{array}{c}9\left(\mathrm{H}_{4,6}\right) \text { or } \\
10\left(\mathrm{H}_{4}\right)\end{array}$ & $10\left(\mathrm{H}_{4}\right), 11\left(\mathrm{H}_{4}\right)$ & $9\left(\mathrm{H}_{4}\right)$ & $9\left(\mathrm{H}_{6,8}\right)$ & $9\left(\mathrm{H}_{4,2}\right)$ & $10\left(\mathrm{H}_{4}\right)$ & $9\left(\mathrm{H}_{4}\right)$ & $10\left(\mathrm{H}_{4,6}\right)$ & $\mathrm{D}$ & $11,12,13,14$ \\
\hline Phospholipid type & PII & PII & PII & PII & PII & PIII & PII & PII & PII & PII & PII & PII & PI & $\mathrm{DPG}+, \mathrm{PG}+\ddagger$ \\
\hline Fatty acid type $\dagger$ & $2 \mathrm{~d}$ & $3 b$ & $2 \mathrm{~d}$ & $2 \mathrm{~d}$ & $3 b$ & $2 c$ & $2 \mathrm{c}$ & $3 b$ & $2 \mathrm{~d}$ & $2 \mathrm{~d}$ & $2 \mathrm{~b}$ & $2 \mathrm{~d}$ & $2 \mathrm{c}$ & $2 c$ \\
\hline $\begin{array}{l}\text { Characteristic } \\
\text { whole-cell sugars }\end{array}$ & $\begin{array}{l}\text { Ara, Gal, } \\
\text { Xyl }\end{array}$ & $\begin{array}{l}\text { Ara, } \\
\text { Xyl }\end{array}$ & $\begin{array}{l}\text { Ara, } \\
\text { Xyl }\end{array}$ & $\begin{array}{l}\text { Ara, Gal, } \\
\text { Xyl }\end{array}$ & $\begin{array}{c}\text { Ara, Gal, } \\
\text { Xyl/Xyl only }\end{array}$ & Xyl & $\begin{array}{l}\text { Ara, Gal, } \\
\text { Xyl }\end{array}$ & $\begin{array}{l}\text { Ara, } \\
\text { Xyl }\end{array}$ & $\begin{array}{l}\text { Ara, } \\
\text { Xyl }\end{array}$ & $\begin{array}{l}\text { Ara, } \\
\text { Xyl }\end{array}$ & $\begin{array}{l}\text { Man, } \\
\text { Xyl }\end{array}$ & $\begin{array}{l}\text { Ara, Gal, } \\
\text { Xyl }\end{array}$ & $\begin{array}{l}\text { Ara, } \\
\text { Xyl }\end{array}$ & ND \\
\hline $\mathrm{G}+\mathrm{C}$ content $(\mathrm{mol} \%)$ & 70 & $71-72$ & $72-73$ & $71-72$ & $71-73$ & $70-72$ & $69-73$ & $71-73$ & ND & 69 & 70 & 71 & $71-73$ & $66-72$ \\
\hline
\end{tabular}

${ }^{\star}$ According to the classification of Lechevalier et al. (1977).

$\dagger$ According to the classification of Kroppenstedt (1985).

‡DPG, Diphosphatidylglycerol; PG, phosphatidylglycerol. 
et al., 1998) and Virgisporangium (Tamura et al., 2001). Although these genera are similar to each other, their cultural, morphological and chemotaxonomic characteristics differ somewhat. Genera that have spore-chains similar to those of strain $\mathrm{K} 97-0003^{\mathrm{T}}$ are Asanoa, Catellatospora, Catenuloplanes, Couchioplanes and Spirilliplanes. The latter three possess motile spores; the two genera that do not possess them, Asanoa and Catellatospora, share this trait with strain K97-0003 ${ }^{\mathrm{T}}$. However, the genera Asanoa and Catellatospora make distinctive spore-chains that are borne directly from the vegetative hyphae that grow on the surface of agar media and do not produce true aerial mycelia. This indicates that strain $\mathrm{K} 97-0003^{\mathrm{T}}$ does not belong to any known genus.

\section{Phylogenetic analysis}

The almost-complete $16 \mathrm{~S}$ rDNA sequence (1496 nt) [positions 10-1506, according to the Escherichia coli numbering system of Brosius et al. (1978)] was determined for strain K97-0003 ${ }^{\mathrm{T}}$; a $1443 \mathrm{nt}$ fragment, between positions 35 and 1475, was used for phylogenetic analysis and compared with $16 \mathrm{~S}$ rDNA database sequences of members of the class Actinobacteria. Phylogenetic analysis based on this large dataset revealed that strain $\mathrm{K} 97-0003^{\mathrm{T}}$ fell within the cluster of the family Micromonosporaceae and was clearly separated from members of the genera Glycomyces and Microbacterium (data not shown). Fig. 2 shows the phylogenetic tree constructed by the neighbour-joining method; this tree revealed that strain $\mathrm{K} 97-0003^{\mathrm{T}}$ branched deeply within the family Micromonosporaceae and belonged to no previously known genera in this family. The tree constructed by the maximum-likelihood method supported this result.

The pattern of $16 \mathrm{~S}$ rDNA signature nucleotides (Stackebrandt et al., 1997) differed only from that of the family Micromonosporaceae at position 502 (A). Sequence similarity values with other members of the family Micromonosporaceae were also low: Catellatospora citrea subsp. citrea, Virgisporangium aurantiacum, Asanoa ferruginea, Dactylosporangium aurantiacum, Pilimelia terevasa, Catenuloplanes japonicus, Verrucosispora gifhornensis, Spirilliplanes yamanashiensis, Micromonospora chalcea, Couchioplanes caeruleus subsp. caeruleus and Actinoplanes philippinensis (91·8-93.0\%).

From the above chemotaxonomic and morphological characteristics and phylogenetic analysis, we propose that strain K97-0003 ${ }^{\mathrm{T}}$ should be classified in a novel genus and species, Longispora albida gen. nov., sp. nov.

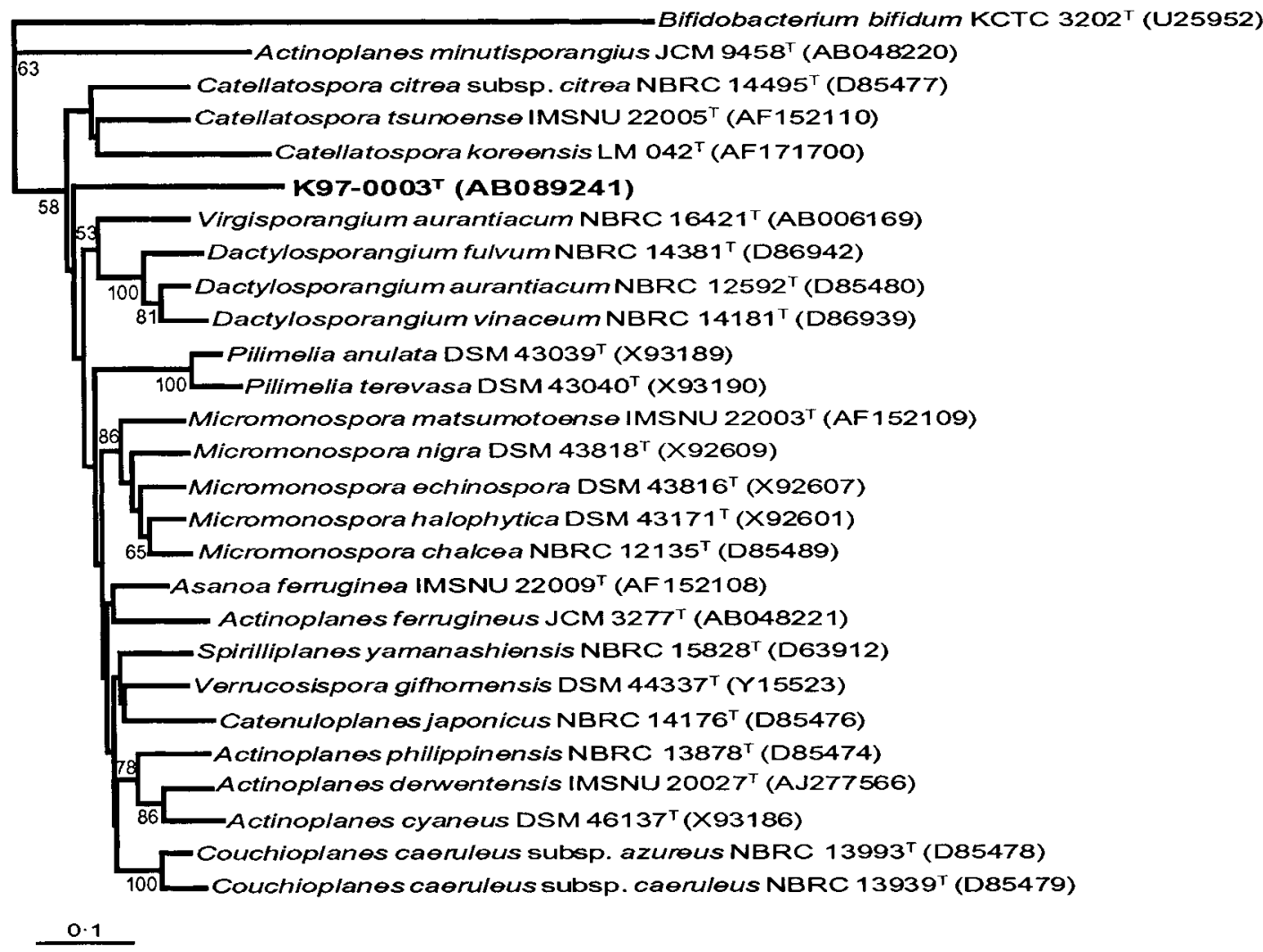

Fig. 2. Phylogenetic tree showing the position of strain $\mathrm{K} 97-0003^{\top}$ based on $16 \mathrm{~S} \mathrm{rDNA}$ analysis. Numbers at nodes indicate the level (\%) of bootstrap support based on neighbour-joining analysis of 1000 resampled datasets. Only values $>50 \%$ are shown. Bar, 1 nucleotide substitution per 100 nucleotides. 


\section{Description of Longispora gen. nov.}

Longispora (Lon.gi.spo'ra. L. adj. longus long; Gr. fem. n. spora spore; N.L. fem. n. Longispora long spore).

Cells are Gram-positive, aerobic, non-acid-fast and nonmotile. Spore-chains are straight and have more than 20 spores on the tip of short sporophores that branch from vegetative mycelia. Cell-wall peptidoglycan contains mesoDAP, glycine and alanine; arabinose, galactose and xylose are detected in whole-cell hydrolysates. The acyl type is glycolyl. Predominant menaquinones are $\mathrm{MK}-10\left(\mathrm{H}_{4}\right)$ and MK-10 $\left(\mathrm{H}_{6}\right)$; a minor component is $\mathrm{MK}-10\left(\mathrm{H}_{8}\right)$. Mycolic acids are not detected. The diagnostic phospholipid is phosphatidylethanolamine (phospholipid type II). Habitat is soil. Mesophilic. The type species is Longispora albida.

\section{Description of Longispora albida sp. nov.}

Longispora albida (al.bi'da. L. fem. adj. albida somewhat white).

General morphological, chemotaxonomic and growth characteristics are as given above for the genus. Spores are cylindrical $(0.4-0.5 \times 1.0-1.4 \mu \mathrm{m})$ and have a smooth surface. Temperature range for growth is $12-37^{\circ} \mathrm{C}$ and the optimum range is $21-33^{\circ} \mathrm{C}$. Growth occurs at $\mathrm{pH}$ 6-9. Melanoid pigment is not produced; positive for reduction of nitrate, liquefaction of gelatin and coagulation and peptonization of milk. D-Glucose is utilized but L-arabinose, D-fructose, myo-inositol, D-mannitol, melibiose, raffinose, L-rhamnose, sucrose and D-xylose are not. Cellulose is not decomposed. Growth is better on gellan gum media than on agar media. No growth in the presence of $2 \% \mathrm{NaCl}$. Predominant cellular fatty acid components are $\mathrm{C}_{17: 1}$, iso$\mathrm{C}_{16: 0}$ and $\mathrm{C}_{18: 1}$. The $\mathrm{G}+\mathrm{C}$ content of the DNA is $70 \mathrm{~mol} \%$.

The type strain is $\mathrm{K} 97-0003^{\mathrm{T}}\left(=\mathrm{NRRL} \mathrm{B}-24201^{\mathrm{T}}=\mathrm{JCM}\right.$ $\left.11711^{\mathrm{T}}\right)$.

\section{ACKNOWLEDGEMENTS}

We thank Mitsuko Matsura for assistance in this study. This study was supported in part by the Grant of the 21st Century COE Program, Ministry of Education, Culture, Sports, Science and Technology (MEXT).

\section{REFERENCES}

Asano, K. \& Kawamoto, I. (1986). Catellatospora, a new genus of the Actinomycetales. Int J Syst Bacteriol 36, 512-517.

Becker, B., Lechevalier, M. P. \& Lechevalier, H. A. (1965). Chemical composition of cell-wall preparation from strains of various formgenera of aerobic actinomycetes. Appl Microbiol 13, 236-243.

Brosius, J., Palmer, M. L., Kennedy, P. J. \& Noller, H. F. (1978). Complete nucleotide sequence of a $16 \mathrm{~S}$ ribosomal RNA gene from Escherichia coli. Proc Natl Acad Sci U S A 75, 4801-4805.

Chiba, H., Inokoshi, J., Okamoto, M. \& 11 other authors (2001). Actinohivin, a novel anti-HIV protein from an actinomycete that inhibits syncytium formation: isolation, characterization, and biological activities. Biochem Biophys Res Commun 282, 595-601.

Collins, M. D., Pirouz, T., Goodfellow, M. \& Minnikin, D. E. (1977). Distribution of menaquinones in actinomycetes and corynebacteria. J Gen Microbiol 100, 221-230.

Couch, J. N. (1950). Actinoplanes. A new genus of the Actinomycetales. J Elisha Mitchell Sci Soc 66, 87-92.

Evtushenko, L. I., Taptykova, S. D., Akimov, V. N., Semyonova, S. A. \& Kalakoutskii, L. V. (1991). Glycomyces tenuis sp. nov. Int J Syst Bacteriol 41, 154-157.

Felsenstein, J. (1985). Confidence limits on phylogenies: an approach using the bootstrap. Evolution 39, 783-791.

Goodfellow, M., Stanton, L. J., Simpson, K. E. \& Minnikin, D. E. (1990). Numerical and chemical classification of Actinoplanes and some related actinomycetes. J Gen Microbiol 136, 19-36.

Hasegawa, T., Takizawa, M. \& Tanida, S. (1983). A rapid analysis for chemical grouping of aerobic actinomycetes. J Gen Appl Microbiol 29, 319-322.

Jiang, C., Xu, L., Yang, Y.-R., Guo, G.-Y., Ma, J. \& Liu, Y. (1991). Actinobispora, a new genus of the order Actinomycetales. Int J Syst Bacteriol 41, 526-528.

Kane, W. D. (1966). A new genus of Actinoplanaceae, Pilimelia, with a description of two species, Pilimelia terevasa and Pilimelia anulata. J Elisha Mitchell Sci Soc 82, 220-230.

Kawamoto, I., Oka, T. \& Nara, T. (1981). Cell wall composition of Micromonospora olivoasterospora, Micromonospora sagamiensis, and related organisms. J Bacteriol 146, 527-534.

Kimura, M. (1980). A simple method for estimating evolutionary rates of based substitutions through comparative studies of nucleotide sequences. J Mol Evol 16, 111-120.

Koch, C., Kroppenstedt, R. M., Rainey, F. A. \& Stackebrandt, E. (1996). 16S ribosomal DNA analysis of the genera Micromonospora, Actinoplanes, Catellatospora, Catenuloplanes, Couchioplanes, Dactylosporangium, and Pilimelia and emendation of the family Micromonosporaceae. Int J Syst Bacteriol 46, 765-768.

Krasil'nikov, N. A. (1938). Ray Fungi and Related Organisms Actinomycetales. Moscow: Akademii Nauk SSSR.

Kroppenstedt, R. M. (1985). Fatty acid and menaquinone analysis of actinomycetes and related organisms. In Chemical Methods in Bacterial Systematics, pp. 173-199. Edited by M. Goodfellow \& D. E. Minnikin. London: Academic Press.

Kudo, T., Nakajima, Y. \& Suzuki, K. (1999). Catenuloplanes crispus (Petrolini et al. 1993) comb. nov.: incorporation of the genus Planopolyspora Petrolini 1993 into the genus Catenuloplanes Yokota et al. 1993 with an amended description of the genus Catenuloplanes. Int J Syst Bacteriol 49, 1853-1860.

Labeda, D. P., Testa, R. T., Lechevalier, M. P. \& Lechevalier, H. A. (1985). Glycomyces, a new genus of the Actinomycetales. Int J Syst Bacteriol 35, 417-421.

Lechevalier, M. P., De Bièvre, C. \& Lechevalier, H. A. (1977). Chemotaxonomy of aerobic actinomycetes: phospholipid composition. Biochem Syst Ecol 5, 249-260.

Lee, S. D. \& Hah, Y. C. (2002). Proposal to transfer Catellatospora ferruginea and 'Catellatospora ishikariense' to Asanoa gen. nov. as Asanoa ferruginea comb. nov. and Asanoa ishikariensis sp. nov., with emended description of the genus Catellatospora. Int J Syst Evol Microbiol 52, 967-972.

Lee, S. D., Kang, S.-O. \& Hah, Y. C. (2000). Catellatospora koreensis sp. nov., a novel actinomycete isolated from a gold-mine cave. Int J Syst Evol Microbiol 50, 1103-1111.

Marmur, J. (1961). A procedure for the isolation of deoxyribonucleic acid from microorganisms. J Mol Biol 3, 208-218. 
Minnikin, D. E., Patel, P. V., Alshamaony, L. \& Goodfellow, M. (1977). Polar lipid composition in the classification of Nocardia and related bacteria. Int J Syst Bacteriol 27, 104-117.

Orla-Jensen, S. (1919). The Lactic Acid Bacteria. Copenhagen, Denmark: Høst \& Son.

Orskov, J. (1923). Investigations into the Morphology of the Ray Fungi. Copenhagen, Denmark: Levin \& Munksgaard.

Pridham, T. G. \& Gottlieb, D. (1948). The utilization of carbon compounds by some Actinomycetales as an aid for species determination. J Bacteriol 56, 107-114.

Rheims, H., Schumann, P., Rohde, M. \& Stackebrandt, E. (1998). Verrucosispora gifhornensis gen. nov., sp. nov., a new member of the actinobacterial family Micromonosporaceae. Int J Syst Bacteriol 48, 1119-1127.

Saitou, N. \& Nei, M. (1987). The neighbor-joining method: a new method for reconstructing phylogenetic trees. Mol Biol Evol 4, 406-425.

Shirling, E. B. \& Gottlieb, D. (1966). Methods for characterization of Streptomyces species. Int J Syst Bacteriol 16, 313-340.

Stackebrandt, E. \& Kroppenstedt, R. M. (1987). Union of the genera Actinoplanes Couch, Ampullariella Couch, and Amorphosporangium Couch in a redefined genus Actinoplanes. Syst Appl Microbiol 9, $110-114$.

Stackebrandt, E., Rainey, F. A. \& Ward-Rainey, N. L. (1997). Proposal for a new hierarchic classification system, Actinobacteria classis. nov. Int J Syst Bacteriol 47, 479-491.

Suzuki, K. \& Komagata, K. (1983). Taxonomic significance of cellular fatty acid composition in some coryneform bacteria. Int J Syst Bacteriol 33, 188-200.

Suzuki, S., Takahashi, K., Okuda, T. \& Komatsubara, S. (1998). Selective isolation of Actinobispora on gellan gum plates. Can J Microbiol 44, 1-5.

Swofford, D. (2001). PAUP*: Phylogenetic Analysis Using Parsimony, version 4.0 beta 8 . Sunderland, MA: Sinauer.

Takahashi, Y., Matsumoto, A., Seino, A., Ueno, J., Iwai Y. \& Ōmura, S. (2002). Streptomyces avermectinius sp. nov., an avermectinproducing strain. Int J Syst Evol Microbiol 52, 2163-2168.

Takeuchi, M. \& Hatano, K. (1998). Union of the genera Microbacterium Orla-Jensen and Aureobacterium Collins et al. in a redefined genus Microbacterium. Int J Syst Bacteriol 48, 739-747.

Tamaoka, J. \& Komagata, K. (1984). Determination of DNA base composition by reverse-phase high-performance liquid chromatography. FEMS Microbiol Lett 25, 125-128.
Tamaoka, J., Katayama-Fujimura, Y. \& Kuraishi, H. (1983). Analysis of bacterial menaquinone mixtures by high performance liquid chromatography. J Appl Bacteriol 54, 31-36.

Tamura, T., Nakagaito, Y., Nishii, T., Hasegawa, T., Stackebrandt, E. \& Yokota, A. (1994). A new genus of the order Actinomycetales, Couchioplanes gen. nov., with descriptions of Couchioplanes caeruleus (Horan and Brodsky 1986) comb. nov. and Couchioplanes caeruleus subsp. azureus subsp. nov. Int J Syst Bacteriol 44, 193-203.

Tamura, T., Hayakawa, M. \& Hatano, K. (1997). A new genus of the order Actinomycetales, Spirilliplanes gen. nov., with description of Spirilliplanes yamanashiensis sp. nov. Int J Syst Bacteriol 47, 97-102.

Tamura, T., Hayakawa, M. \& Hatano, K. (2001). A new genus of the order Actinomycetales, Virgosporangium gen. nov., with descriptions of Virgosporangium ochraceum sp. nov. and Virgosporangium aurantiacum sp. nov. Int J Syst Evol Microbiol 51, 1809-1816.

Taylor, H. D., Knoche, L. \& Granville, W. C. (editors) (1958). Color Harmony Manual, 4th edn. Chicago: Container Corporation of America.

Thiemann, J. E., Pagani, H. \& Beretta, G. (1967). A new genus of the Actinoplanaceae: Dactylosporangium, gen. nov. Arch Mikrobiol 58, 42-52.

Thompson, J. D., Higgins, D. G. \& Gibson, T. J. (1994). CLUSTAL W: improving the sensitivity of progressive multiple sequence alignment through sequence weighting, position-specific gap penalties and weight matrix choice. Nucleic Acids Res 22, 4673-4680.

Tomiyasu, I. (1982). Mycolic acid composition and thermally adaptative changes in Nocardia asteroides. J Bacteriol 151, 828-837.

Uchida, K. \& Aida, K. (1977). Acyl type of bacterial cell wall: its simple identification by a colorimetric method. J Gen Appl Microbiol 23, 249-260.

Vobis, G. (1989). Actinoplanetes. In Bergey's Manual of Systematic Bacteriology, vol. 4, pp. 2418-2450. Edited by S. T. Williams, M. E. Sharpe \& J. G. Holt. Baltimore: Williams \& Wilkins.

Waksman, S. A. (1961). Classification, identification, and description of genera and species. In The Actinomycetes, vol. 2, pp. 1-363. Baltimore: Williams \& Wilkins.

Yokota, A., Tamura, T., Hasegawa, T. \& Huang, L. H. (1993). Catenuloplanes japonicus gen. nov., sp. nov., nom. rev., a new genus of the order Actinomycetales. Int J Syst Bacteriol 43, 805-812.

Zlamala, C., Schumann, P., Kämpfer, P., Valens, M., RossellóMora, R., Lubitz, W. \& Busse, H.-J. (2002). Microbacterium aerolatum sp. nov., isolated from the air in the 'Virgilkapelle' in Vienna. Int J Syst Evol Microbiol 52, 1229-1234. 